II. No distinct caudal peduncle, the dorsal and anal fins nearly reaching the caudal; subopercle entire or indistinctly serrated; dorsal with 16 or 17 spines.

Ventral reaching far beyond origin of anal ; length of head much less than depth of body, $3 \frac{1}{4}$ to $3 \frac{1}{3}$ in total length; maxillary hardly extending to below anterior border of eye ........................ fasciolata, Blgr.

Ventral extending to origin of anal; length of head equal to depth of body, $2 \frac{1}{2}$ to $2 \frac{2}{3}$ in total length; maxillary extending to below anterior fifth or anterior third of eye .........................

Anabas (Ctenopoma) Petherici, Gthr., does not occur in the rivers flowing into the Atlantic. Specimens from the Gaboon have recently been referred to it by Günther; but I find on careful examination that they really belong to $A$. (C.) Kingsleya, Gthr., which differs from the White Nile species in the absence of spines on the scales behind the eye. The depth of the body is $2 \frac{1}{3}$ to $2 \frac{1}{2}$ in the total length $\left(2 \frac{2}{3}\right.$ to 3 in $A$. Petherici), and the anal spines number more frequently 9 than 10.

Ct. microlepidotum, Gthr., is identical with Sandelia Bainsii, Casteln. I have not yet been able to ascertain which specific name has priority.

The genera Ctenopoma, Spirobranchus, and Sandelia cannot be upheld. The types of all three have the airbladder bifid behind and prolonged into the caudal region, as in Anabas, and the palatine teeth may be absent in specimens otherwise referable to Ctenopoma.

XXXIX.-Description of Two new Butterflies collected by Major E. M. Woodward in Nandi, Equatorial Africa. By Emily Mary Sharpe,

\title{
Family Nymphalidæ.
}

Neptis Woodwardi, sp. n.

Allied to $N$. incongrua, Butler (P. Z. S. 1896, p. 112, pl. vi. fig. 2), from Nyasaland.

This species differs from the allied form in the absence of light spots on the inner margin of the primaries, and no spots are visible at the end of the discoidal cell, so that the 


\section{On Two new Butterfies from Equatorial Africa.}

whole of the basal half of the wing is uniform brown. The band on the secondaries which crosses the centre of the wing from the costa to the inner margin is ochraceous and slightly broader than in $N$. incongrua, which has this band white.

Underside. General colour pale brown, the nervules and a patch near the discoidal cell of the primaries darker brown. Secondaries pale brown, the nervules and hind marginal border slightly darker, with a very distinct and dark brown patch well pronounced towards the apex. The light markings on the upperside of both wings are very distinctly reproduced below.

Expanse $2 \cdot 1$ inches.

Hab. Nandi, Uganda Protectorate, 13th March, 1898 (E. M. W.).

\section{Family Acræidæ.}

Planema nandensis, sp. n.

Allied to $P$. Alava, Dewitz, but altogether smaller. The blackish band on the primaries which crosses from the discoidal cell unites with the hind margin, and is distinctly narrower than in P. fluva, as are also the brown apical and hind marginal borders. Secondaries entirely ochre-yellow, the brownish hind margin being very much narrower as compared with that of the allied form.

Underside. The dark brown borders of the upper surface are reproduced on the underside by a mere representation of dusky brown, but the cross-band on the primaries at the end of the discoidal cell is equally strongly marked as on the upper surface, though there is no connexion with the hind marginal border. 'The secondaries have a cluster of nine minute spots near the base, the central area of the wings being ochre-yellow, with the nervules and marginal border dusky brown.

Expanse $1 \cdot 7$ inch.

Hab. Nandi, Uganda Protectorate, 16th March, 1898 (E.M. W.).

This species is doubtless nearly allied to Acrcea disjuncta of Mr. Grose-Smith (Nov. Zool. v. p. 35̃1, 1898), but there are many points of difference, which will be readily seen on comparing his description with the one given above. 


\section{$2 \mathrm{BHL}$ Biodiversity Heritage Library}

Sharpe, Emily Mary Bowdler. 1899. "XXXIX.—Description of two new butterflies collected by Major E. M. Woodward in Nandi, Equatorial Africa." The Annals and magazine of natural history; zoology, botany, and geology 3, 243-244. https://doi.org/10.1080/00222939908678115.

View This Item Online: https://www.biodiversitylibrary.org/item/63341

DOI: https://doi.org/10.1080/00222939908678115

Permalink: https://www.biodiversitylibrary.org/partpdf/58817

\section{Holding Institution}

University of Toronto - Gerstein Science Information Centre

\section{Sponsored by}

University of Toronto

\section{Copyright \& Reuse}

Copyright Status: NOT_IN_COPYRIGHT

This document was created from content at the Biodiversity Heritage Library, the world's largest open access digital library for biodiversity literature and archives. Visit BHL at https://www.biodiversitylibrary.org. 